\title{
Choice-Making in Rendering Culture-Bound Elements in Literary Translation: A Case Study on the English Translation of 《灵魂像风》
}

\author{
SONG Meihua ${ }^{1}$ \\ ${ }^{1}$ Department of Translation and Interpreting, School of Foreign Languages, Southwest Jiaotong University, \\ Chengdu, China \\ Correspondence: SONG Meihua, School of Foreign Languages, Southwest Jiaotong University, Chengdu \\ 610031, China. E-mail: songmeihua@home.swjtu.edu.cn
}

\author{
Received: August 6, 2014 Accepted: September 7, 2014 Online Published: September 22, 2014 \\ doi:10.5539/elt.v7n10p13 URL: http://dx.doi.org/10.5539/elt.v7n10p13
}

\begin{abstract}
How to render culture-bound elements into a foreign language remains one of the most challenging tasks for all translators, especially, when the source text is a literary one. To retain the aesthetic effects and other stylistic features of importance, some argue that choice can be made from either domestication or foreignization with foreignization being more encouraged for the sake of preserving the foreignness of the original text. This article is a case study of the translator's (author of this article) conscious choice-making in rendering culture-bound elements in her tentative Chinese-to-English translation of 《灵魂像风》, a documentary literary work on Tibetan culture and life by a famous Chinese writer Ma Lihua. Based on Sperber and Wilson's Relevance Thoery and some of the translator's previous studies, optimal foreignization is proposed for the rendition of culture-bound elements by analyzing the dynamic cognitive nature of the target reader in text processing and terming "strategy" in a broad sense. In the tentative translation, optimal foreignizaiton is a strategy the trasnlator consciously adopts as an overall guidance for her subsequent choice-making in rendering different categories of culture-bound elements. By reflecting upon her decision-making involved in translating the culture-bound elements, the translator makes decisions in the layers of meaning, structure, function, image, and music, and sometimes image or music might go before meaning in the translator's decision-making as long as the meaning is processible.
\end{abstract}

Keywords: choice-making, culture-bound elements, optimal foreignization, 《灵魂像风》

\section{About the Source Text 《灵魂像风》}

Language is an indispensable element in the realization of the verbal act. It is a necessary precondition for communication.

Translation is a dual act of communication. It presupposes the existence, not of a single code, but of two distinct codes, the "source language" and the "target language." The fact that the two codes are not isomorphic creates obstacles for the translative operation. This explains why linguistic questions are the starting-point for all thinking about translation. (Brisset, 1990/1996; Venuti, 2004, p. 337)

Therefore, it is justifiable and necessary to look first at the linguistic and stylistic features of the prelude and the first chapter of the source text (ST), 《灵魂像风》, for which the translator did the tentative translation (Note 1).

\subsection{About the ST Author and Her Works-Linguistically Focused}

The source text, 《灵魂像风》, was written by Ma Lihua, a famous writer in Modern China, whose documentary literary works authentically depict the daily life and living of the Tibetan common people. She has been living in Tibet for more than 20 years, experiencing and deeply researching into Tibetan's daily life and living. In the process of composing her documentary work, like 《灵魂像风》, she has even stayed at the homes of the Tibetan common people for certain periods of time. Her books, like 《走过西藏》 (Note 2), the collection of her three well-known works, one of which is 《灵魂像风》, are written in Chinese and can be located at the library of such universities as Cornell or Harvard.

She writes in very natural, plain, yet also exquisite and prosaic (literary) Chinese language. Her work is an authentic portrayal of Tibetan daily life and involves lots of elements about Tibetan religion, customs, names, art, etc., foreign not only to the English speakers but also to many who know Chinese language well. Chinese language is sharply distinct from English language. More challenging in the tentative translation is the rendition 
of the cultural elements or specifications, including those translated by Ma Lihua from Tibetan language to Chinese. Thus, when rendering the culture-loaded elements involved, the authentic value of the original languages (both Chinese and Tibetan) can not be neglected. The decision-making upon strategies and methods for the translation at some point must take the three languages and cultures into account.

\subsection{Definition and Categorization of Culture-Bound Elements}

By Wikipedia (Net. 1), Culture can be defined as all the ways of life including arts, beliefs, and institutions of a population that is passed down from generation to generation. Culture has been called "the way of life for an entire society." As such, it includes codes of manners, dress, lanugages, religiou, rituals, norms of behavior such as law and morality, and systems of belief as well as the art.

People from different nations share the same experience, affection and cognition to a certain extent despite the disparate cultural differences in the communities they live in. However, Chinese language and English language are so different it is almost impossible to achieve a translated text without leaving any clue of being translated. If so, the foreignness entailed in the original must be sacrificed for the sake of linguistic and even cultural naturalization in the target. Based on the definition of culture and linguistic features of 《灵魂像风》, explicit culture-bound elements can be easily found in the source text related to people's daily life style, customs, rituals, religions, legends and folklore tales, etc. The more challenging difficulty in rendering the culture-bound elements lies in the translation of the translation (from Tibetan to Chinese) in the original.

Tibetan, as a language, is totally different from Chinese. The author, living in Tibet for so many years, chooses to write all specifications peculiar to Tibetan culture in Chinese. Basically, the culture-loaded elements in terms of the three languages of Chinese, Tibetan and English, can be categorized into two broad groups. One falls into the context of general Chinese language and culture; the other is peculiar to Tibetan language and culture. Based on their identity in Chinese, Tibetan, and English, the culture-bound elements in the second group are subcategorized into several subgroups. Since they are Tibetan cultural specifications, they are all identified in Tibetan language and culture, and are marked with "+"; most of them tend to be defaults in English language and culture, and are marked with "_"; they might or might not be traced in the context of Chinese language and culture. See Table 1 as follows:

Table 1. Sub categorizations of tibetan-culture-bound elements in relation to Chinese and English

\begin{tabular}{|c|c|c|c|c|}
\hline $\begin{array}{l}\text { Cultural Identity } \\
\text { Categorizations }\end{array}$ & Tibetan & Chinese & English & Examples \\
\hline 1) & + & + & + & “牧民 (mù mín)”; “酥油茶 (sū yóu chá)” \\
\hline 2) & + & - & + & $\begin{array}{l}\text { Famous names with conventional English } \\
\text { translations, for example, “布达拉宫 (bù dá lāa } \\
\text { gōng)”, “大昭寺 (dà zhāo sì)”, “青藏高原 } \\
\text { (qīng zàng gāo yuán)”, etc. }\end{array}$ \\
\hline 3) & + & + & - & $\begin{array}{l}\text { big holidays, for example, “却果节 (què guǒ } \\
\text { jiée)”, “望果节 (wàng guǒ jié) }\end{array}$ \\
\hline 4) & + & - & - & $\begin{array}{l}\text { Names of Tibetan people (real and legendary), } \\
\text { animals, places, clothes, rituals, etc.; }\end{array}$ \\
\hline
\end{tabular}

Note. "+" means "cultural elements are identified in the language and culture"; "_" means "defaults in the language and culture".

Besides, there is also a third group in the category of culture-bound elements in this case study. It is the mixture of the author's writing style and the musical Tibetan language found when the author of the source text translates the original Tibetan lyrics of songs at some big events into her natural, plain, yet also exquisite Chinese.

As to the rendition of culture-bound elements, it is natural for a translator to bring the foreignness bounded to the source cultural elements to the target reader as long as the linguistic convention of the target language allows. So foreignizing plays a big part in this regard.

The empirical study conducted by Zheng $(2008$, p. 261) on choice-making in translating process indicates that a translator uses translation theories or principles as the guidance, consciously or unconsciously, during choice-makings or decision-makings. The traslator in her tentative translation is also guided by some overall strategy in her own practice, especially, when she has to do some conscious decision-makings in rendering the 
culture-bound elements. It is what she (2008, pp. 211-215) has argued for the "optimal foreignizaiton" in rendering culture-bound elements in literary translation. However, it is necessary to clarify this notion for further discussion of more aspects invloved in rendering culture-bound elements in a documentary literary work like 《灵魂像风》.

\section{Optimal Foreignization: Conscious Choice-Making of Strategy for Rendering Culture-Bound Elements}

Domesticating and foreignizing in English, or "tonghua" and "yihua" in Chinese, are taken by many scholars as a strategy or method a traslator decides to adopt in translative operation, although the former pair might also involve some other notions. In Lawrence Venuti's works (1992; 1995), he does not clarify foreignizing as a strategy or a method, but clues are left in a book he edited-"The Translation Studies Reader", from which we can conclude he naturally terms it as translating strategy.

Seclections can be grouped to explore assumptions about language use (instrumental vs heremeneutic), theoretical condepts (translatability and relative autonomy, equivalence and shifts, reception and function), translation strategies (free vs literal, sense-for-sense vs word-for-word, domesticating vs foreignizing), particularly neres or text types (humanistic, pragmatic), and various cultural and political issues (identify and ideology, power and minority, disiplines and institutions). (Venuti, 2004, p. 7)

Therefore, in this study, the translator uses foreigizing as a strategy but terms it in a broad sense, which will be further elaborated in 2.2. In addition, optimal foreignization is argued for being a strategy functioning as guidance the translator consciously follows in her translating process, rather than specific methods taken in making decisions on how to translate certain culture-bound elements.

\subsection{Optimal Foreignization in Theoretical Sense}

Unlike domesticated translation, foreignized translation likely suggests such expressions as "otherness", "alienation", "oddness", "obstacles of communication", "disrespect of the target reader", etc. Also, as opposed to a desired optimum processibility, foreignization, in its communicative sense, likely involves more processing costs of effors. Accordingly, many translators feel reluctant to foreignize in translating for fear that it would be too odd, absurd, and even frustrating to the target reader. Nevertheles, foreignizated traslation plays a big part in bringing the source culture to the target reader, and it might not inevitably turn out to be odd translation. Besides, Foreignizing, as a translating strategy to preserve and reveal the foreignness of the original, its significance and necessity are directly or indirectly underscored by the modern trends of translation studies (Venuti, 2004, p. 482; Bassnet \& Lefevere, 1998, p. 136; Snell-Hornby, 2006, p. 175). With the cultural turn of translation studies, translation plays an active role in optimally communicating the cultural otherness of the original.

Seen as domestic inscription, never quite cross-cultural communication, translation has moved theories towards an ethical reflection wherein remedies are formulated to restore or preserve the foreignness of the foreign text. (Venuti, 2004, p. 483)

Regarding the instrumental function of translation in terms of assumptions about language use, it enables a successful communication between two (usually sharply distinct) cultures. In the tentative translation of 《灵魂 像风》, which involves aspects of three distinct languages and cultures, foreigizing, or rather, optimal foreignization, is consciously taken as a strategy in the interest of bringing elements pertaining to the source culture to the target reader. Then what is optimal foreignization? In what sense could it be taken as guidance by the translator for decision-makings in rendering culture-bound elements in her tentative translation?

The psycho-cognitive aspects of human communication could to a certain extent tell that the applicability of foreignizing is predictable and even rectifiable in preserving and revealing the foreignness of the original and enabling the successful communication between two distinct cultures as well. Apparently, given its communicative nature in the first sense, translation, for whatever purposes, cannot neglect the target audience; otherwise, where lies in the point of its existence? Based on Relevance Theory (Sperber \& Wilson, 1986, pp. 154-162; Sperber \& Wilson, 1995, pp. 83-172), which provides a universal frame of human communication from a psycho-cognitive viewpoint: the ostensive-inferential communication, and some recent studies on Schema Theory, my previous research (2003) has attempted to propose a cognitive-communicative foreignization paradigm by exploring its theoretical sense through analyses of the reader's psycho-cognitive nature in text processing: the dynamic description of cognitive context in Relevance Theory, the hierarchical nature of schematic structure and the reader's potential schemata refreshment upon the interaction of text and linguistic. Although in processing foreignization more efforts could be required, which is adverse to human's automatic desire for the minimum of efforts taken in inference, the principle of relevance in Relevance Theory universally underlying human's communication draws the target reader into active adaptations (perhaps at some point 
reluctantly) and searches for hints through textual lines in that any ostensive-inferential communication has a prerequisite of relevance. The target reader's dynamic psycho-cognitive nature in text processing and their tendency to make dynamic adaptations automatically or consciously enable the translator to make an overall dynamic judgment of the potential communicability of foreignization from the target reader's perception. In order to make the foreignization processible, the translator may need to adopt different methods in foreignizing.

In translating practice, while keeping the target reader in mind and making sound judgment of the processibility of the translated text, a translator could also be aware that, the translated text, whether domesticated or foreignized, is considered by some scholars as the third text (Goethe, 1819, p. 65). It can be considered, so to speak, as the original text clothed in a target language, but it is apparently neither the original nor a text originally written in the target language. In a utopian view, the translated text creates its potential audience or "community" (Venuti, 2004, pp. 501-502). No matter how domesticated it is, it is expected to optimally represent the foreignness of the foreign text, a view that is more and more shared among modern translation researchers ; no matter how foreignized it is, it is expected to be (potentially) processible, otherwise, it will lose its sense of existence for the loss of its potential audience or "community". For a translated text, especially, one between two sharply distinct cultures and language systems, say, a translated text from Chinese to English, the English reader might not expect its translation to be as fluent and natural as their English in all aspects. In other words, even though the foreignizing translation might sound strange, it does not follow that it is not communicable. What's more, even with regards to literary translation, where there is a stricter requirement for the aesthetic aspects of literature, both linguistically and culturally, it does not follow that domesticating is a safe strategy to retain the aesthetic or artistic effects/elements entailed in the original.

Therefore, a translator could be more encouraged to adopt a foreignizing approach in her/his real translating practice, for the sake of preserving the foreignness of the original text and correspondingly enrich the target language or culture with the full play of that foreignness. Given its increasingly significant function in cross-cultural communication, its communicative nature, its third-text identity, and the target reader's dynamic congitive nature in text processing, it is necessary and applicable to optimally foreignize culture-bound elements in translation, especially, translation of literature, which basically involves various aspects of culture.

Therefore, by borrowing a term from Sperber \& Wilson's "optimal relevance", what a translator tries to approach with cognitive-communicative foreignization is actually optimal foreignization rather than utter foreignization. It adheres to the communicative nature of translation by keeping the target reader in mind and transcends it by taking foreignness realization of the original as a translating goal. It is not something tangible or absolute; it is foreignization in degrees.

\subsection{Optimal Foreignization as a Strategy}

According to Wikitionary (Net. 2), strategy is defined as follows:

1) The science and art of military command as applied to the overall planning and conduct of warfare;

2) A plan of action intended to accomplish a specific goal;

3) The art of using similar techniques in politics or business.

As art/science/plan to achieve a certain goal, strategy is a general term and inevitably involves specific techniques or methods. Foreignizing, as a translating strategy, serves in a sense as an overall guidance; optimal foreignization is a strategy that stands in degrees rather than on an extreme foreignization or even domestication. In translation practice, it does not simply mean to totally plunge the target reader into the darkness of otherness. Instead, in achieving the goal of preserving the foreignness of the original, various techniques or methods may be employed, some of which might stand quite close to domestication. Foreignization might be varied and adapted in degrees, say, total, or partial. If the target reader can learn about the foreignness of the original and can process its meaning (sometimes globally in the whole text), it can be considered as a method of foreignizing to achieve the goal of preserving foreignness. This is what the translator has termed "optimal foreignization", a conscious choice she has made to serve as guidance in translating the culture-bound elements in her tentative translation.

\section{Choice-Making of Methods in Rendering Culture-Bound Elements: A Case Study}

As is argued, strategy involves different adaptable methods in realizing the goal. Reflecting upon the translation of the prelude and the first chapter of 《灵魂像风》, the translator has employed the following methods of optimal foreignizaiton to achieve the goal of showing both the foreignness of the original (Chinese and Tibetan) and the aesthetic effecs of literature according to the categorizations of the culture-bound elements that have been made above. 
As to the choice-making of strategies in translating process, Zheng (2008, pp. 260-262) puts forward the optimal strategies in layers of meaning, structure, function and monitoring, which means a translator first of all faces the sequences of translation problems and makes decisions in the above four layers, and then resolves problems and generates the translation by using different strategies. "Strategy" here is similar in meaning to "methods", obviously different from what the translator has argued about strategy in this study. The case study would not go that far in analyzing all layers of choices. However, by reflecting upon her decision-makings involved in translating the culture-loaded elements, the translator makes decisions in the layers of meaning, structure, function, image, and music, and sometimes image or music might go before meaning in the translator's decision-making as long as the meaning is processible.

\subsection{Rendering Culture-Bound Elements Peculiar to Chinese}

Lexically, some expressions in Chinese have been used generations after generations and therefore have become heavily culture-loaded images. Thanks to human shared experience or affect, their foreignization is intelligible, or proves to be processible in a global text despite seemingly “odd” foreignness. Take “有心栽花、无心插柳” (Note 3). In the English language, the fluent and natural one is "We aim for the goose and hit the gander" or "We get something as the product of making something else", but considering meaning and image, image is decided to be retained with meaning understandable, so the preferred option is "We harvest willows as the product of growing flowers." This is understandable in meaning, esp. in the global processing in context; meanwhile, its poetic (hopefully) yet odd (likely) way of speaking might draw the reader's attention to its linguistic freshness. The goal of foreignizing is not to produce a deliberate odd rendition, but actually to preserve to some extent the foreignness of Chinese language and culture.

Besides, syntactically, in Chinese, more short simple sentences are used. Sentences are structured and cohered by textual logic and meanings rather than adjacent elements. For a complicated sentence, the subordinate clause usually goes before the principal one. In reading the translation, the English reader might accumulate a sense of this "foreignness". No deliberate effort is made to restructure the sentence the way English does, but globally, it is processible and optimistically not too absurd with the feedback from some English native speakers as proof readers.

\subsection{Rendering Culture-Bound Elements Peculiar to Tibetan}

Rendition of culture-bound elements peculiar to Tibetan language and culture indicates that decisions under optimal foreignization upon methods are made in layers of meaning, structure, function and "monitoring" as well. Here the "monitoring", a term borrowed from Dr. Zheng Binghan, according to the translator's reflection upon her two versions of translation at different stages, includes the accumulated knowledge of translation, the change in some of the Tibetan-cultural elements and also the transltor's increased awareness of taking the three cultural systems into full consideration. See Table 2.

Table 2. Two versions of translation of Tibetan-culture-bound elements (Note 4)

\begin{tabular}{|c|c|c|c|}
\hline \multirow{2}{*}{$\begin{array}{l}\text { Examples of Different Groups of } \\
\text { Tibetan-culture-bound Elements }\end{array}$} & \multirow{2}{*}{$\begin{array}{l}\text { Constructed Corpus (Note 5): } \\
\text { Different Versions of Eglish } \\
\text { Translation }\end{array}$} & \multicolumn{2}{|c|}{ Versions Taken by the Translator } \\
\hline & & Version 1 & Version 2 \\
\hline $\begin{array}{l}\text { “牧民 (mù mín)”; } \\
\text { “酘油茶 (sū yóu chá)” }\end{array}$ & $\begin{array}{l}\text { rancher, herdsman, cattleman, } \\
\text { herder, etc. } \\
\text { milk tea; butter tea; yak-butter } \\
\text { tea }\end{array}$ & yak-butter tea & butter tea \\
\hline $\begin{array}{l}\text { Famous names with conventional } \\
\text { English translations, for example, } \\
\text { “布达拉宫 (bù dá lā gōng)”, “大 } \\
\text { 昭寺 (dà zhāo sì)”, “青藏高原 } \\
\text { (qīng zàng gāo yuán)”, etc. }\end{array}$ & $\begin{array}{l}\text { Potala Palace } \\
\text { Jokhan Temple } \\
\text { Qinghai-Tibet Plateau }\end{array}$ & $\begin{array}{l}\text { Potala Palace } \\
\text { Jokhan Temple } \\
\text { Qinghai-Tibet } \\
\text { Plateau }\end{array}$ & $\begin{array}{l}\text { Potala Palace } \\
\text { Jokhan Temple } \\
\text { Qinghai-Tibet } \\
\text { Plateau }\end{array}$ \\
\hline $\begin{array}{l}\text { big fetivals, for example, “却果节 } \\
\text { (què guó jié)”, “望果节 (wàng } \\
\text { guǒ jié) }\end{array}$ & $\begin{array}{l}\text { No version available } \\
\text { Harvest Thanksgiving Festival }\end{array}$ & $\begin{array}{l}\text { Queguo Festival } \\
\text { Wangguo Festival }\end{array}$ & $\begin{array}{l}\text { Spring Plow } \\
\text { Festival } \\
\text { Autumn Harvest } \\
\text { Festival }\end{array}$ \\
\hline $\begin{array}{l}\text { Names of Tibetan people (real } \\
\text { and legendary), animals, places, } \\
\text { clothes, rituals, etc. e.g. 犏牛 }\end{array}$ & $d z o$ & $d z o$ & $d z o$ \\
\hline
\end{tabular}


Table 2 could be elaborated as follows:

1) Some culture-loaded elements can find their respective "equivalents" in Chinese and English, but due to different cultures, the connotations are different. Consider “牧民 (mù mín)". There are different options in English, like "rancher", "herdsman", "cattleman", "herder", etc. A rancher, in the US, for example, is associated with somebody who owns a pasture and herds of domestic animals being leisurely fed on a vast green land. However, “牧民 (mù mín)” in Tibet lives a comparatively hard life by herding their yaks, cattle or sheep far away from home in summer due to the tough natural plateau conditions. Also, “牧民 (mù mín)” and “农民 (nóng mín) have the same suffix “民 (mín)". The common English translation of the latter is "farmer" and therefore the preferred translation of the former is "herder". In deciding on this translation, the translator obviously tries in a way to retain linguistic form of the original by putting “民 (mín)” to "-er” . Another example is “酥油茶 (sū yóu chá)”, which is put into English as “milk tea” by some Tibetan restaurants. But they are not exactly the same, especially in taste and main compositions. Milk tea is mainly a mixture of milk and tea; while“酥油茶 (sū yóu chá)”, as a specialty food in Tibetan plateau area, contains a large portion of “酥油 (sū yóu)", similar to butter, but in Tibet, the authentic “酥油 (sū yóu)" is fat extracted from the milk of yaks. So "yak-butter tea" was taken as the first version of translation. Although it is not as natural as "milk tea", its connotation seems to be closer to the original. However, later on, "yak-butter tea" turns out to be replaced by "butter tea" in that by traveling to Tibet and some Tibetan farms, the translator has found that “酥油 (sū yóu)" is extracted fat not always from the milk of yaks but also from that of horses or cows. “酥油茶” is put into "yak-butter tea" in Lonely Planet-Tibet, but "butter tea" in many other cases. Therefore, "butter tea" instead of "yak-butter tea" is the final choice at this stage of the tentative translation by the translator even though "yak-butter tea" might bring more foreignness and is equally processible to the target reader. However, translation should be done by taking both culture systems into consideration, including the changing factors or trends.

2) Some terms are translated to Chinese from Tibetan, but they have their conventionally established English translation, such as “布达拉宫 (bù dá lā gōng)”, “大昭寺 (dà zhāo sì)” and “青藏高原 (qīng zàng gāo yuán)”, whose English translations have been respectively conventionalized as "the Potala Palace", "Jokhang Temple" and "Qinghai-Tibet Plateau". It is not difficult to translate them for there are corresponding English translations, established by usage yet preserving the original foreignness.

3) Some expressions, like some big Tibetan festivals are even well-known in other parts of China other than Tibet. For example, “却果节 (què guǒ jié)” and “望果节 (wàng guǒ jié)” are Chinese expressions translated from Tibetan, but only by the characters, one can grasp something thematic of the festivals for harvest: the former is a festival held upon spring plow by Tibetan farmers to "deposit" their harvest at the Goddess of Land, whereas the latter is to "withdraw" their harvest in autumn harvest from the Goddess and thank her for her guarding and blessing. The two terms originate from Tibetan language, but they have been conventionally used and culture-loaded in Chinese language. They were put into Chinese phonetic alphabets: Queguo Festival and Wangguo Festival in the first version in that the translator predicted they were processible in the global text since there were lots of descriptions of how the festivals are going on in the source text. However, with the help of a native English speaker as a proof reader, the translator gave priority to meaning rather than form, through which the translation is more intelligible to the English reader with the foreignness of the source culture retained.

4) One common frustration in rendering《灵魂像风》 is how to translate so many names-names of Tibetan people (real and legendary), animals, places, clothes, rituals, and so on, which are translated from Tibetan and even appear foreign in the source text to Chinese readers. Putting them into Chinese phonetic alphabets is certainly not a good way, because if so, the Chinese foreignness in terms of form might be retained, but not a bit of the Tibetan. A suggested way is putting them back into Tibetan phonetic alphabets. One reason is that the restoration of their original Tibetan identity can generate something like Eugene A. Nida's "functional/dynamic equivalence" in that they help the English reader to be aware they are reading about Tibetan culture just as Chinese readers are. Another reason remains that the foreignness is retained, esp. for the sake of the aim of translation. Could we say, at some point, foreignizing turns out to arrive at the effect of domesticating in terms of "functional/dynamic equivalence"?

Decision-making at this stage actually does not seem that difficult in that a corpus can be made for translation. However, under optimal foreignization, the translator consciously makes choices between meaning, form, function and sometimes "monitoring" as well.

\subsection{Rendering the Rendered-Lyrics}

As to the third group of culture-bound elements categorized in 2.2, two examples are given to show decisions 
made by the translator on how to render lyrics of songs which are translated from Tibetan into Chinese in favor of the aesthetic effects of literature as well as the foreignness of Tibetan language. For almost all rituals or ceremonies, the Tibetan people sing and dance. The documentary literary work 《灵魂像风》 involves lots of marvelous lyrics of songs in various events. They are originally in Tibetan language, but translated into Chinese in the source text. The foreignizing method chosen is to render them into English from Chinese, not convert them reversely into Tibetan. The lyrics of the songs depict the Tibetan people's feelings, thoughts, and expectations of life. The "pre-original" Tibetan is so sonorous and rhythmic, and the original Chinese is so impressive with the author's concise and recitable sentences. If put them back to Tibetan phonetic alphabets , except the utter foreignness to the English speaker, they would make no sense at all and no processing will be made even in the global text. If put them into exactly what Chinese characters indicate, they would be rid of some of its color and liveliness as lyrics in Tibetan. So the suggested way might be to put them into concise and rhythmic English. In doing this, the translator is making decisions in layers of meaning, funtion and music as well. This is not to violate or domesticate the original, but rather, in a sense, to allow the target reader to learn more about the foreignness about both Chinese and Tibetan languages entailed in the original documentary literary work. An example of lyrics of the chorus at Spring Plow ceremonies, and their tentative translation is shown as follows (Note 6):

Original: 太阳从何处升起, 太阳自东方升起,

世界的土地河流, 是温暖阳光赐予;

Translation: From where does the sun rise? From East the sun rises.

World's waters and lands, the warm sunshine grants.

Original: 月亮从何处升起, 月亮自山顶升起,

没有太阳和月亮, 世界将暗淡无光;

Translation: From where does the moon rise? From Mountaintop the moon rises,

When Sun and Moon are not there, there'll be light nowhere.

Another example: lyrics of the songs sang by an old lady, a cheerful Tibetan villager (Note 7).

Original: 新酿的青稞酒格外清香。邦金梅朵啦。

夏天盛开着邦金梅朵, 欢乐的人们在此相聚。

Translation: Meadow flowers blooming in a summer day,

People teem together - cheerful and gay,

Fresh barley wine sweetening its scent away.

Ah, my meadow flowers!

Reflecting upon the above two examples, the translator makes decisions for the actual translating methods with "music" being highlighted. In this way, the foreignness of the Tibetan lyrics or the characteristics of the language and culture is perserved and communicated to the target reader by creating more rhythmic music in translation. It is not domestication in that the translation is true to the pre-original Tibetan language and the target reader is brought to it rather than it is brought to the target reader.

\section{Conclusion}

With regard to optimal foreignization, it is impossible even in theory for the translator to describe and master in full details the interplay between the target text and the target reader's mind in terms of schemata and relevance. However, what counts more is the translator, meanwhile as a target reader, based on the target reader's dynamic psycho-cognitive nature in processing, can pre-justify the processibility of foreignization in translative operation. The foreignization of some culture-bound elements might seem unacceptable at a certain point but turns out to be processible in the global communication of the whole text. When the processing of the foreignization is foreseen to meet drawbacks, the translator can then act as a mediator and make some remedies to provide linguistic or text structural clues, so that the target reader can possibly adapt their initial assumptions to the new information and adjust their cognitive change and refreshment favorably to communication. Accordingly, some frequently discussed methods of foreignizing, like "addition", "omission" "annotation", "literal translation with footnotes or cut-in notes", etc., can then have their underlying guidance.

As a translating strategy serving as guidance, optimal foreignization involves subsequent adaptable methods in order to achieve the goal of preserving the foreignness and realizing the identity of the original. Take the 
tentative translation of 《灵魂像风》, the strategy of optimal foreignization is a choice consciously made by the translator to function as guidance for her sub-decision-makings in rendering different categories of culture-bound elements. Choice-makings or decision-makings under optimal foreignization involve priority being given to image, music, form or function with a precodition that meaning is processible or potentially processible.

In real translating process, one might seldom take pains to figure out what methods to take at what point. Different translators may have different habits or methods of translating without specifically being conscious of what strategies or subsequent methods one is adopting. Also, one may summarize different methods one has adopted if one reflects upon one's own translation. The case study is but a tentative translation of a translator who is not a native speaker of English, therefore, it must be open to criticism and questions. Anyway, hopefully, it might provide some implications for practical work of rendering culture-bound elements that fall within the similar situation.

\section{Acknowledgements}

The research is supported by a university-level grant (SWJTU11BR134) by Southwest Jiaotong University under "Hundred Talents Program" of Chinese Academy of Sciences. The author is also grateful to Prof. Carrol Coates who did the proofreading of the translation script as a native speaker at TRIP (Translation Research and Instruction Program), State University of New York at Binghamton; and to her colleagues and friends Prof. Wang Weimin and Dr. Dai Ruoyu for their constructively critiquing the manuscript.

\section{References}

Bassnet, S., \& Lefevere, A. (1998). Constructing cultures: Essays on literary translation. Clevedon: Multilingual Matters.

Brisset, A. (1990, 1996). The search for a native language: translation and cultural identity (R. Gill \& R. Gannon, Trans.). In L. Venuti (Ed.), The translation studies reader (pp. 337-368). New York and London: Routledge.

Goethe, J. W. (1819). Translations (S. Sloan, Trans.). In L. Venuti (Ed.), The translation studies reader (pp. 64-66). New York and London: Routledge.

Snell-Hornby, M. (2006). The turns of translation studies: New paradigm or shifting viewpoints? Amsterdam/Philadelphia: John Benjamins Publishing Company.

Song, M., \& Xia, W. (2003). Paradigmatic construction of cognitive-communicative foreignization and its implications for translation studies. Journal of Southwest Jiaotong University (Social Science), 4, 71-76. Chengdu: Southwest Jiaotong University Press.

Song, M. (2003). Paradigmatic construction of cognitive-communicative foreignization (Master's thesis, Southwest Jiaotong University, Chengdu, China). Retrieved from http://202.115.72.1/idl/Publish/ ShowDocument.aspx?sumid=10689

Song, M. (2008). Optimal foreignization of culture-bound elements in literary translation-with analysis of the English translation of 《灵魂像风》. In N. Hartmann (Ed.), Proceedings of the $49^{\text {th }}$ Annual Conference of the American Translators Association (pp. 211-221). Orlando, USA.

Sperber, D., \& Wilson, D. (1986). Relevance: Communication and cognition. Oxford, UK: Blackwell Publishers Ltd.

Sperber, D., \& Wilson, D. (1995). Relevance: Communication and cognition (2nd ed.). Oxford, UK: Blackwell Publishers Ltd.

Venuti, L. (1992). Rethinking translation: Discourse, subject, ideololgy. London and New York: Routledge.

Venuti, L. (1995). The translator's invisibility: A history of translation. London and New York: Routledge.

Venuti, L. (2004). Introduction. In L. Venuti (Ed.), The translation studies reader (pp. 1-9). New York and London: Routledge.

Venuti, L. (2004). Translation, community, utopia. In L. Venuti (Ed.), The translation studies reader (pp. 482-502). New York and London: Routledge.

Xiang, H. J. (2011). Chinese-English and English-Chinese dictionary for translation of Tibetological Terminology. Beijing: China's National Terminological Publisher.

Zheng, B. H. (2008). Choice-making in the Process of English-to-Chinese Translation: An Empirical Study (Doctoral dissertation, Nan Yang Technological University, Singapore). 


\section{Notes}

Note 1. The English translation of 《灵魂像风》 in this study refers to a tentative translation of its prelude and the first chapter by the author of this article and Prof. Carrol Coates who did the proofreading as a native speaker. The tentative translation is officially approved by the ST author, Ma Lihua.

Note 2. 《走过西藏》, revised version, published by China Tibetology Publishing House in 2007, is a three-volume collection of three famous works by Ma Lihua, one of which is 《灵魂像风》, the other two are 《藏北游历》 and 《西行阿里》. Most of her works are documentary and provide authentic depictions of Tibetan life and culture. 《走过西藏》 is so popular in China that it is usually the first to be considered in selecting a book about Tibetan life and culture.

Note 3. see page 1 in the first chaper of 《灵魂像风》.

Note 4. The first version of the English translation was made by the translator in the year 2008, earlier than the publication of Chinese-English and English-Chinese Dictionary for Translation of Tibetological Termimology which was published by China Tibetology Publishing House in 2011.

Note 5. The corpus is constructed on the basis of Chinese-English and English-Chinese Dictionary for Translation of Tibetological Termimology, Lonely Planet China, Lonely Planet Tibet, etc.

Note 6. see page 3 in the first chaper of 《灵魂像风》.

Note 7. see page 10 in the first chaper of 《灵魂像风》.

\section{Copyrights}

Copyright for this article is retained by the author (s), with first publication rights granted to the journal.

This is an open-access article distributed under the terms and conditions of the Creative Commons Attribution license (http://creativecommons.org/licenses/by/3.0/). 